\title{
Chemodiversity of dissolved organic matter in the Amazon Basin
}

\author{
Michael Gonsior ${ }^{1}$, Juliana Valle ${ }^{2,3}$, Philippe Schmitt-Kopplin ${ }^{3,4}$, Norbert Hertkorn ${ }^{3}$, David Bastviken ${ }^{5}$, Jenna Luek ${ }^{1}$, \\ Mourad Harir ${ }^{3}$, Wanderley Bastos ${ }^{6}$, and Alex Enrich-Prast ${ }^{2,5}$ \\ ${ }^{1}$ Chesapeake Biological Laboratory, University of Maryland Center for Environmental Science, Solomons, MD 20688, USA \\ ${ }^{2}$ Departamento de Ecologia, Universidade Federal do Rio de Janeiro, Rio de Janeiro, 21941-901, Brazil \\ ${ }^{3}$ Research Unit Analytical BioGeoChemistry, Helmholtz Zentrum München, 85764 Neuherberg, Germany \\ ${ }^{4}$ Analytical Food Chemistry, Technische Universität München, 85354 Freising-Weihenstephan, Germany \\ ${ }^{5}$ Department of Thematic Studies - Environmental Change, Linköping University, 58183 Linköping, Sweden \\ ${ }^{6}$ Laboratory of Environmental Biogeochemistry, Universidade Federal do Rondônia, Rodovia, 76801-974, Brazil
}

Correspondence to: Michael Gonsior (gonsior@umces.edu)

Received: 1 March 2016 - Published in Biogeosciences Discuss.: 15 March 2016

Revised: 31 May 2016 - Accepted: 17 June 2016 - Published: 29 July 2016

\begin{abstract}
Regions in the Amazon Basin have been associated with specific biogeochemical processes, but a detailed chemical classification of the abundant and ubiquitous dissolved organic matter (DOM), beyond specific indicator compounds and bulk measurements, has not yet been established. We sampled water from different locations in the Negro, Madeira/Jamari and Tapajós River areas to characterize the molecular DOM composition and distribution. Ultrahighresolution Fourier transform ion cyclotron resonance mass spectrometry (FT-ICR-MS) combined with excitation emission matrix (EEM) fluorescence spectroscopy and parallel factor analysis (PARAFAC) revealed a large proportion of ubiquitous DOM but also unique area-specific molecular signatures. Unique to the DOM of the Rio Negro area was the large abundance of high molecular weight, diverse hydrogendeficient and highly oxidized molecular ions deviating from known lignin or tannin compositions, indicating substantial oxidative processing of these ultimately plant-derived polyphenols indicative of these black waters. In contrast, unique signatures in the Madeira/Jamari area were defined by presumably labile sulfur- and nitrogen-containing molecules in this white water river system. Waters from the Tapajós main stem did not show any substantial unique molecular signatures relative to those present in the Rio Madeira and Rio Negro, which implied a lower organic molecular complexity in this clear water tributary, even after mixing with the main stem of the Amazon River. Beside ubiquitous DOM at average $\mathrm{H} / \mathrm{C}$ and $\mathrm{O} / \mathrm{C}$ elemental ratios, a distinct and significant unique DOM pool prevailed in the black, white
\end{abstract}

and clear water areas that were also highly correlated with EEM-PARAFAC components and define the frameworks for primary production and other aspects of aquatic life.

\section{Introduction}

With an average of about $200000 \mathrm{~m}^{3} \mathrm{~s}^{-1}$ and $\sim 20 \%$ of the global freshwater discharge, the Amazon River transports larger amounts of riverine freshwater into the ocean than the next seven biggest river systems on Earth combined. Dissolved organic matter (DOM) processed and transported within the Amazon Basin is therefore of global importance as $32-36 \mathrm{Tg}$ of organic carbon (of which $60-70 \%$ is dissolved) are exported seaward of Óbidos annually (Richey et al., 1990; Moreira-Turcq et al., 2003). Repeated attempts have been made to describe the origin and fate of particulate and dissolved organic matter throughout the Amazon River and its tributaries using a variety of methodologies. The sources of riverine organic matter $(\mathrm{OM})$ have been identified through isotopic analysis of $\delta^{13} \mathrm{C}, \delta^{18} \mathrm{O}$ and $\delta^{15} \mathrm{~N}$ (Hedges et al., 1992, 2000; Quay et al., 1992; McClain et al., 1997; Maurice et al., 2002; Moreira-Turcq et al., 2013). Humic acids, fulvic acids and lignin concentrations have also provided information on the OM sources (Hedges et al., 1992, 2000; Ertel et al., 1986), whereas labile DOM components such as saccharides and amino acids (Hedges et al., 1994), as well as bacterial consumption (Benner et al., 1995) and biological and photo-degradation observations (Amado et al., 2006), have 
provided information on OM reactivity and bioavailability. ${ }^{13} \mathrm{C}$ NMR and optical spectroscopy have been used to understand bulk characteristics and functional groups of Amazon organic matter (OM) (Maurice et al., 2002; Luciani et al., 2008; Patel-Sorrentino et al., 2002), and OM age has also been analyzed using $\delta^{14} \mathrm{C}$ measurements (Townsend-Small et al., 2007), but a detailed molecular understanding has not yet been established for large tributaries of the Amazon River basin.

Amazon tributaries vary in their coloration and opacity due to their origin and reactivity and have traditionally been classified as "black waters", "white waters" and "clear waters" (Sioli, 1950). These three water types play a continuing role in the transformation of $\mathrm{OM}$, due to mediating light availability for aquatic life or photoreactivity. Black waters are influenced by chromophoric DOM (CDOM) and have low particulate mineral content (Sioli, 1950; Leenheer, 1980). It has been suggested that drainage areas of black water systems are characterized by moist, acidic, hydric soils that allow for leaching of terrestrially derived plant matter, like lignins, tannins and other plant materials that also contribute to the CDOM (Leenheer, 1980). White waters make up $\sim 2 / 3$ of the Amazon Basin (Sioli, 1950; Junk, 1984), exhibit low DOM levels and are less acidic ( $\mathrm{pH} 6.6 \pm 0.2)$ when compared to the black waters of the Rio Negro $(\mathrm{pH}$ $4.5 \pm 0.9$ ) (Duncan and Fernandes, 2010). The "white" color reflects a high mineral particle load due to drainage and erosion of calcic sedimentary deposits (Horbe et al., 2013) originating largely from the Andes mountains. Clear waters drain kaolinite clays (Leenheer, 1980) and contain high concentrations of iron and aluminum oxides that may adsorb humic acids (Philippe and Schaumann, 2014). Because of removal of CDOM and suspended sediments prior to the water entering the main stem of these clear water Amazon tributaries, the CDOM and suspended particle levels are typically very low in these systems. As a result, clear waters are less lightlimiting and can support higher phytoplankton biomass, if the generally low nutrient levels are elevated (Costa et al., 2013; Sioli, 1950; Richey et al., 1990). High precipitation in combination with low infiltration of floodplain soils produce rapid overland and shallow subsurface flow responses to precipitation events across the Amazon Basin which carry particulate organic matter (POM) and DOM to the river from the surrounding river corridor (McClain et al., 1997; Johnson et al., 2006).

High CDOM in black waters and suspended sediment concentrations in white waters limit light and therefore the autochthonous production of organic matter (Costa et al., 2013); accordingly, allochthonous inputs dominate the organic matter pool (Ertel et al., 1986; Hedges et al., 1994; Townsend-Small et al., 2007). In clear waters, light is abundant (Costa et al., 2013) but nutrients are limited, and as a result, OM is still expected to be influenced by allochthonous input. However, agriculture and urbanization along clear waters can supply additional nutrients and therefore increase au- tochthonous OM production with potential consequences for the DOM pool. These specific physicochemical properties of these three main types of waters in the Amazon Basin are expected to exhibit distinctly different organic matter signatures.

High bacteria counts $\left(\sim 10^{9} \mathrm{~L}^{-1}\right)$ have been observed in black and white waters, with peaks during annual floods (Benner et al., 1995) when terrestrial-derived DOM enters the river (Moreira-Turcq et al., 2013). The biodegradable DOM appeared to be rapidly removed from these waters, causing bacterial carbon limitation (Benner et al., 1995). Clear waters showed phosphorus limitation during high water periods, but also carbon limitation due to low carbon quality (Farjalla et al., 2002). Younger, biologically available organic matter is preferentially respired upstream and the apparent $\delta^{14} \mathrm{C}$ age of POM increases downstream (Benner et al., 1995; Townsend-Small et al., 2007). Therefore, a certain proportion of the DOM likely reflects the recalcitrant behavior after microbial metabolism.

The unique DOM environments found within the Amazon Basin, which are ultimately the drivers of aquatic life, have yet to be resolved on a fine scale. It is unclear how previous work on bulk DOM, optical properties, a few specific target compounds, isotopes or microbial processes reflects the authentic chemical diversity intrinsic to the complex OM found in black, white and clear waters. Therefore, we investigated the chemodiversity of these three water types across the Amazon Basin by employing non-target Fourier transform ion cyclotron resonance mass spectrometry (FTICR-MS) interfaced with soft electrospray ionization (ESI), which has enabled the characterization of thousands of individual molecular ions in complex DOM mixtures (Gonsior et al., 2011, 2013; D'Andrilli et al., 2010; Tremblay et al., 2007; Ward et al., 2013; Hertkorn et al., 2013; Liu et al., 2011; Stubbins et al., 2010; Stenson et al., 2003). By combining this technique with advanced optical characterization, excitation emission matrix (EEM) fluorescence spectroscopy and parallel factor analysis (PARAFAC), we assess similarities and differences in DOM composition between different waters of the Amazon Basin.

Using these techniques, we attempted to answer the following questions. (a) What is the overall chemodiversity of DOM in the Amazon Basin, and do distinct differences in DOM composition exist between major Amazon tributaries and the flooded area? (b) How well do the simple optical properties represent the overall molecular composition of DOM as described by FT-ICR-MS in tropical ecosystems? Satisfactory comprehension of these relationships would have large implications for the understanding of aquatic food webs and also for predicting further transport and processing of DOM in the Amazon. 


\section{Materials and methods}

Water samples from the main stem of the Madeira (and its small tributary Rio Jamari), Negro and Tapajós River were collected in duplicates using $1 \mathrm{~L}$ precombusted Pyrex glass bottles in May 2013. The bottles were filled in the main stem of the river just below the surface. In addition, 9-10 lakes, that were flooded by the individual rivers at the time of sampling, were sampled in the same manner near the cities of Santarém (confluence of Tapajós and Amazon River: Rio Tapajós area), São Carlos (Rio Madeira area) and Novo Airão (Rio Negro area) (Fig. S1 in the Supplement). The sampling sites in the Rio Tapajós area included samples from flooded clear water lakes adjacent to the main stem of the Rio Tapajós and flooded lakes that were located after the confluence of Rio Tapajós and the main stem of the Amazon River. However, the sampling sites after the confluence were still dominated by Rio Tapajós water. The collected samples were filtered and solid phase extracted either directly after collection (aboard river boats) or within $3 \mathrm{~h}$ after collection, when smaller boats were used for sampling.

\subsection{Solid-phase extraction}

All $1 \mathrm{~L}$ water samples were filtered through precombusted $\left(500^{\circ} \mathrm{C}\right)$ Whatman $\mathrm{GF} / \mathrm{F}$ glass fiber filters, acidified to $\mathrm{pH}$ 2 by using high-purity formic acid $(98 \%)$ and subsequently solid-phase-extracted (SPE). The SPE procedure used has been previously described in detail (Dittmar et al., 2008), but it was modified and formic acid was used instead of $\mathrm{HCl}$ to prevent possible chloride ion adduct formation in the ionization source of the FT-ICR-MS (Boutegrabet et al., 2012). Briefly, SPE-cartridges (Agilent, Bond Elut PPL, $1 \mathrm{~g}$ resin) were activated with methanol (Chromasolv, Sigma Aldrich), rinsed with acidified ultrapure water (Milli-Q, $\mathrm{pH}$ 2 , formic acid) and the acidified water samples were gravityfed through the cartridges at a flow rate of $\sim 10 \mathrm{~mL} \mathrm{~min}^{-1}$.

Subsequently, the cartridges were rinsed again with acidified Milli-Q water to remove remaining sample solution, dried and eluted with $10 \mathrm{~mL}$ high-purity methanol (Chromasolv, Sigma Aldrich) into pre-cleaned $40 \mathrm{~mL}$ amber glass vials. Methanolic samples were then kept on ice during the 2week sampling period and later kept at $-18^{\circ} \mathrm{C}$. Methanolic extracts are stable when kept at $-18^{\circ} \mathrm{C}$ for extended periods of time (Flerus et al., 2011). The adsorption efficiency of the used SPE method was in general $90-98 \%$ of the chromophoric DOM (CDOM) (measured by EEM fluorescence) and $60-70 \%$ of the dissolved organic carbon (DOC). All samples were run in duplicates. DOC concentrations for all samples ranged between 3 and $10 \mathrm{mg} \mathrm{L}^{-1}$, so only $1 \mathrm{~L}$ of sample water was run through the SPE cartridge to prevent overloading the $1 \mathrm{~g}$ PPL resin.

\subsection{Nutrients, chlorophyll, DOC, total dissolved nitrogen (TDN) and total dissolved phosphorus (TDP) analyses}

Small $(40 \mathrm{~mL})$ aliquots of each water sample were filtersterilized $(0.2 \mu \mathrm{m}$, Whatman GD/X Cellulose acetate filters) and stored on ice prior to analysis. Total dissolved nitrogen (TDN) and phosphorus analyses were performed by an automated $\mathrm{FOSS}^{\circledR}$ colorimetric flow injection analysis system, according to the quality control guidelines recommended by the manufacturer. The detection limit for TDN and total phosphorus was $5 \mu \mathrm{g} \mathrm{L}^{-1}$ and standard deviations ranged between 1.2 and $2.3 \mu \mathrm{g} \mathrm{L}^{-1}$ and between 1.5 and $2.1 \mu \mathrm{g} \mathrm{L}^{-1}$, respectively. DOC was analyzed in triplicates by oxidation with sodium persulfate in a titanium oven under high temperature and high pressure by using an automatic carbon analyzer (InnovOx Sievers Total Organic Carbon (TOC) Analyzer) with a detection limit of $0.05 \mathrm{mg} \mathrm{L}^{-1}$ and standard deviation between 0.01 and $0.02 \mathrm{mg} \mathrm{L}^{-1}$. Chlorophyll $a$ was extracted and analyzed according to a previously published procedure (Centre national pour l'exploitation des océans (France), 1983) and analyzed using a Turner Designs fluorometer (Model Trilogy) with a detection limit of $0.01 \mathrm{mg} \mathrm{L}^{-1}$.

\subsection{Ultrahigh-resolution mass spectrometry}

All SPE samples were analyzed using negative-mode electrospray ionization and a Bruker Solarix 12 Tesla FT-ICR-MS located at the Helmholtz Zentrum Munich, Germany. Details about the FT-ICR-MS analyses used in this study have been described previously (Gonsior et al., 2011; Hertkorn et al., 2013). Briefly, methanolic samples were diluted $1: 20$ with methanol and then directly injected into the electrospray at a flow rate of $120 \mu \mathrm{L} \mathrm{min}^{-1}$. Five hundred scans with a time domain of four megawords were averaged and the averaged spectra were post-calibrated using a list of known DOM internal calibrants. A mass accuracy of less than $0.2 \mathrm{ppm}$ deviation from the actual mass was achieved (less than the mass of an electron). Multiple charged ions in flow injection FT-ICR-MS analysis may occur, dependent on the solution concentration and electrospray condition parameters (Gaspar et al., 2009): however, in our analysis we only encountered singly charged ions as described previously (Stenson et al., 2002). The achieved mass resolution was in routine full scan 500000 at $\mathrm{m} / \mathrm{z} 400$, and exact unambiguous molecular formulae were assigned to the observed molecular ions up to a $m / z$ of $800 \mathrm{Da}$ (Hertkorn et al., 2008).

Negative-mode ESI typically generates several thousands of different $\mathrm{m} / \mathrm{z}$ ions, but this ionization technique is largely biased toward organic acids because of their high ionization efficiencies. For example, alcohols and saccharides do not ionize efficiently in electrospray, and hence signals of these compound classes are largely lost in complex DOM mixtures analyzed by FT-ICR-MS. On the other hand, DOM contains 
a large diversity of highly polar and polyfunctional easily ionizable compounds (e.g., organic acids), operationally also classified as fulvic and humic acids.

Van Krevelen diagrams (van Krevelen, 1950) were used to visualize the elemental ratios of unambiguously assigned molecular formulae. Kendrick plots (Kendrick, 1963) are also useful to determine members of homologous series, but we used a modified Kendrick plot, where the Kendrick mass defect (KMD) is divided by another independent parameter $z^{*}$ (Stenson et al., 2003) to describe homologous series and molecular formulae only spaced by $\mathrm{CH} 2$. This ratio of KMD divided by $z^{*}\left(\mathrm{KMD} / z^{*}\right)$ enabled the unambiguous determination of homologous series and an enhanced visualization (much better resolution between homologous series). Additional details about this approach have previously been described (Shakeri Yekta et al., 2012).

\subsection{Excitation emission matrix fluorescence and parallel factor analysis}

CDOM was recovered almost quantitatively ( $>90 \%$ ) using the described SPE method and enabled a direct comparison of FT-ICR-MS results and optical properties of Amazon DOM. SPE-DOM samples were prepared for optical analyses using $100 \mu \mathrm{L}$ of the methanolic extract that was completely dried under pure nitrogen, redissolved in $10 \mathrm{~mL}$ Milli$\mathrm{Q}$ water and further diluted with Milli-Q water $(1: 20)$. The $\mathrm{pH}$ of the solutions of all redissolved samples ranged between 4 and $5 \mathrm{pH}$ units. Optical properties are highly dependent on $\mathrm{pH}$, and hence a narrow $\mathrm{pH}$ range was beneficial to accurately compare samples. Excitation emission matrix (EEM) fluorescence measurements of dried and redissolved SPE-DOM were measured using a temperature-controlled Jobin Yvon Aqualog fluorescence spectrometer. The emission was recorded over the range from 200 to $600 \mathrm{~nm}$ for excitation wavelengths ranging from 240 to $600 \mathrm{~nm}$ at $3 \mathrm{~nm}$ intervals. Fluorescent intensities were Raleigh-scatteringcorrected, inner-filter-corrected by using the absorbance data and normalized to a STARNA quinine sulfate fluorescent standard of $1 \mathrm{ppm}$ concentration. The statistical parallel factor analysis (PARAFAC) of fluorescence data (Stedmon et al., 2003) was applied in this study to the EEM data set by using drEEM, which was developed in Matlab and utilizes the N-way toolbox (Murphy et al., 2013). Several models were tested and a five-component model was developed on the normalized data (Fig. S2). This model showed the best results in terms of separation between components, residuals and core consistency. Normalization was reversed prior to split-half validation of six subsets of the five-component model (Murphy et al., 2013). The five-component model was split-half-validated and explained $99.86 \%$ of the variability, and the results of the split-half validation are given in supplementary information (Fig. S3). The unscaled and true scores of the components (Fmax) for each sample were exported and used for all subsequent statistical analyses.

\subsection{Multivariate statistical analysis}

Data mining and the application of multivariate statistics is increasingly important to be able to analyze very complex data sets. Examples of such multivariate approaches are hierarchical cluster analysis (HCA) and principal component analysis (PCA) that have been recently applied to ultrahighresolution mass spectrometry (Sleighter et al., 2010; Werner et al., 2008; Stubbins et al., 2014) and EEM-PARAFAC (Chen et al., 2010). In this study, PCA and HCA were applied to mass-spectrometry-based data sets of all collected spectra and their exact mass lists and intensities. The duplicate samples were first averaged and resulted in up to 16000 variables ( $m / z$ ions). A data matrix was compiled of all averaged samples and mass lists, where $m / z$ ions were matched in a narrow $0.2 \mathrm{ppm}$ error window. This matrix was then normalized by subtracting the average value from each data point and dividing it by the standard deviation (Bro and Smilde, 2014). The resulting FT-ICR-MS mass list data sheet was then converted into a resemblance matrix by using Spearman's rank correlations and used to create hierarchical clusters. The same data set was also used in the PCA analysis of FT-ICR-MS data. A similar approach was undertaken for the EEM-PARAFAC data set.

In an additional analysis, the two normalized data sets (FTICR-MS and EEM-PARAFAC) were combined to be able to determine hierarchical clusters on the variables $(\mathrm{m} / \mathrm{z}$ ions and their intensities and EEM-PARAFAC Fmax values) and to create a microarray. This approach is in analogy to genetic data, where the expression levels of large numbers of genes can be simultaneously visualized. In our case, molecular formulae and their associated $\mathrm{m} / \mathrm{z}$ ion intensities would be in analogy to specific DNA sequences and concentrations. This approach enabled the generation of heat maps (software: TM4-Multi Experiment Viewer) and hierarchical clusters of all molecular formula assigned to $\mathrm{m} / \mathrm{z}$ ions and also which $m / z$ ions or molecular formula co-varied with EEM-PARAFAC Fmax values. This approach successfully depicted hierarchical clusters of specific classes of molecular formulae with distinct and confined chemodiversity as expressed in van Krevelen diagrams within the $\mathrm{CHO}$, CHNO and CHOS pools (Fig. S7). Hence, subsets of molecular formulae that correlated well with EEM-PARAFAC components were depicted.

\section{Results and discussion}

Representative FT-ICR-MS spectra from each area are provided in Fig. 1. The mass spectrum of the Rio Negro sample, in comparison to the other areas, clearly showed much higher intensities of hydrogen-deficient $\mathrm{m} / \mathrm{z}$ ions in the low and high molecular weight ranges (Figs. 1 and 2). Further evaluation of these initial results by intensity-weighted parameters confirmed the trend from higher mass to lower mass 


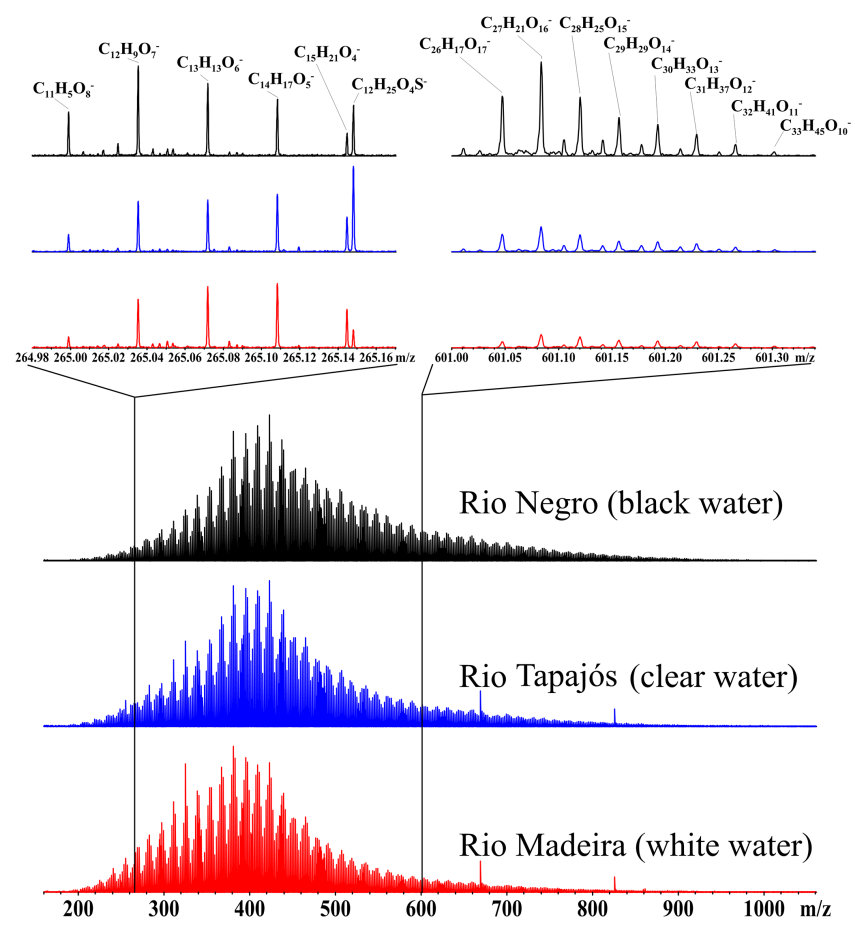

Figure 1. Ultrahigh-resolution FT-ICR mass spectra of SPE-DOM isolated from the main stem of the Rio Negro, Rio Madeira and Rio Tapajós, Amazon, Brazil and the stacked relative abundances of all ions at nominal mass 265 and 601 for all three river systems (note the differences in peak intensity for individual $\mathrm{m} / \mathrm{z}$ peaks).

DOM molecules in the order Rio Negro, Rio Tapajós and Rio Madeira (Table 1). For example, the intensity-weighted center of mass with assigned $\mathrm{CHO}$ formulae was $453 \mathrm{Da}$ in Rio Negro, $428 \mathrm{Da}$ in Rio Tapajós and $419 \mathrm{Da}$ in Rio Madeira. Counts of double-bond equivalents (DBEs) and DBE-oxygen (DBE-O) also followed the same decreasing pattern from Rio Negro, Rio Tapajós and Rio Madeira (Table 1). The intensityweighted averaged oxygen to carbon $(\mathrm{O} / \mathrm{C})$ and hydrogen to carbon $(\mathrm{H} / \mathrm{C})$ elemental ratios did not follow the same decreasing trend and indicated that the displacement of higher molecular weight DOM in the Rio Negro towards lower molecular weight in the Madeira or Tapajós rivers was not associated with a change in overall elemental ratios. Somewhat similar trends were observed for the molecular ions that represented nitrogen-containing compounds, but the numbers of assigned $\mathrm{CHNO}$ formulae were approximately $30 \%$ lower in the Rio Negro samples. Similarly, ions with sulfur-containing formulae were of very low abundance in the Rio Negro, when compared to higher occurrence in the Rio Tapajós and even higher proportions in the Rio Madeira (Table 1).

Detailed molecular formula assignments of duplicate SPEDOM samples from the Rio Negro area (black water), Rio Tapajós area (clear water) and Rio Madeira area (white water) in both the main stem of the river as well as flooded adjacent lakes revealed an overall molecular composition of


Ubiquitous Amazon DOM signatures
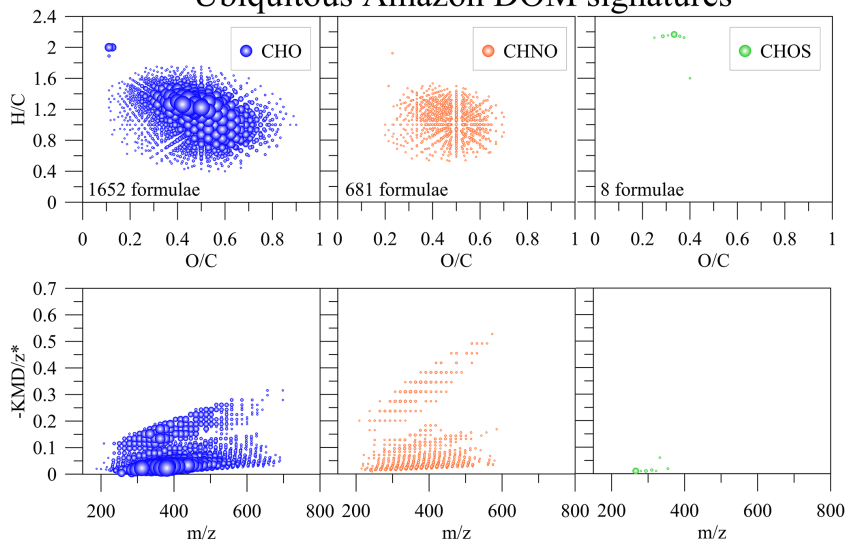

Figure 2. Van Krevelen diagrams of the total and the ubiquitous $m / z$ ions in all Amazon SPE-DOM samples analyzed by FT-ICRMS.

Amazon DOM that was remarkably diverse (Fig. 2). CHO formulae covered almost the entire area of chemically reasonable $\mathrm{O} / \mathrm{C}$ and $\mathrm{H} / \mathrm{C}$ ratios, but $\mathrm{CHNO}$ and CHOS formulae also showed extensive compositional variance. The chemodiversity of all Amazon DOM signatures was characterized by 6118 assigned molecular formulae occurring in duplicate samples of which $43 \%$ were of hetero-atomic nature, i.e., $\mathrm{CHNO}$ and CHOS formulae (Fig. 2, top six panels). Common molecular formulae across all samples referred to $47 \%$ of $\mathrm{CHO}, 31 \% \mathrm{CHNO}$, but less than $2 \%$ of $\mathrm{CHOS}$ molecular formulae (Fig. 2). However, distinct area-specific differences in relative abundances applied to many of the ubiquitous DOM $m / z$ ions (Fig. 2, lower six panels).

A simple computation of unique signatures $(\mathrm{m} / \mathrm{z}$ ions $)$ from each sampling area (Fig. 3) was combined with molecular formulae assignments and revealed that the Rio Negro area was characterized by unique, abundant and numerous high molecular weight compounds in a rather confined area within the van Krevelen diagram, indicative of a large diversity of polyphenolic-type compounds with high $\mathrm{O} / \mathrm{C}(0.5$ $0.8)$ and low $\mathrm{H} / \mathrm{C}(0.4-0.7)$ ratios, presumably highly de- 
Table 1. Differences in SPE-DOM between the Rio Negro, Rio Tapajós and Rio Madeira identified by ESI-FT-ICR-MS.

\begin{tabular}{llrcccccc}
\hline \multicolumn{7}{c}{ Intensity-weighted average values of all assigned molecular formulae (180-800 Da) } \\
\hline Formulae & Sample & $n$ & Center of mass & $\Delta \mathrm{O}: \mathrm{C}_{\mathrm{W}}$ & $\Delta \mathrm{H}: \mathrm{C}_{\mathrm{w}}$ & $\Delta \mathrm{DBE}_{\mathrm{W}}$ & $\Delta \mathrm{DBE}_{\mathrm{W}}-\mathrm{O}$ & $\Delta \mathrm{DBE}_{\mathrm{W}}: \mathrm{C}$ \\
\hline \multirow{2}{*}{$\mathrm{CHO}$} & Negro & 3130 & 453 & 0.51 & 1.05 & 11.15 & 0.31 & 0.524 \\
& Tapajós & 3298 & 428 & 0.49 & 1.12 & 10.04 & 0.13 & 0.494 \\
& Madeira & 3151 & 419 & 0.51 & 1.10 & 9.93 & -0.03 & 0.504 \\
\hline \multirow{2}{*}{$\mathrm{CHNO}$} & Negro & 1362 & 429 & 0.49 & 0.99 & 11.58 & 1.85 & 0.590 \\
& Tapajós & 1975 & 413 & 0.49 & 1.02 & 10.92 & 1.68 & 0.580 \\
& Madeira & 2088 & 408 & 0.50 & 1.01 & 10.91 & 1.64 & 0.592 \\
\hline \multirow{2}{*}{ CHOS } & Negro & 58 & 313 & 0.22 & 1.84 & 2.49 & -0.99 & 0.143 \\
& Tapajós & 286 & 315 & 0.30 & 1.66 & 3.65 & -0.75 & 0.237 \\
& Madeira & 399 & 357 & 0.49 & 1.21 & 7.15 & -0.23 & 0.460 \\
\hline
\end{tabular}

Note: $\Delta \mathrm{O}: \mathrm{C}_{\mathrm{W}}$ denotes intensity-weighted averaged oxygen to carbon ratios of assigned molecular formulae; $\Delta \mathrm{H}: \mathrm{C}_{\mathrm{W}}$ denotes intensity-weighted averaged hydrogen to carbon ratios of assigned molecular formulae; $\triangle \mathrm{DBE} \mathrm{W}_{\mathrm{W}}$ denotes intensity-weighted averaged double-bond equivalency; $\triangle \mathrm{DBE}_{\mathrm{W}}-\mathrm{O}: \triangle \mathrm{DBE}_{\mathrm{W}}$ with numbers of oxygen atoms subtracted, $\triangle \mathrm{DBE}_{\mathrm{W}}: \mathrm{C}$ : carbon normalized $\triangle \mathrm{DBE}_{\mathrm{W}} \cdot n$ : number of assigned molecular formulae to $m / z$ molecular ions.
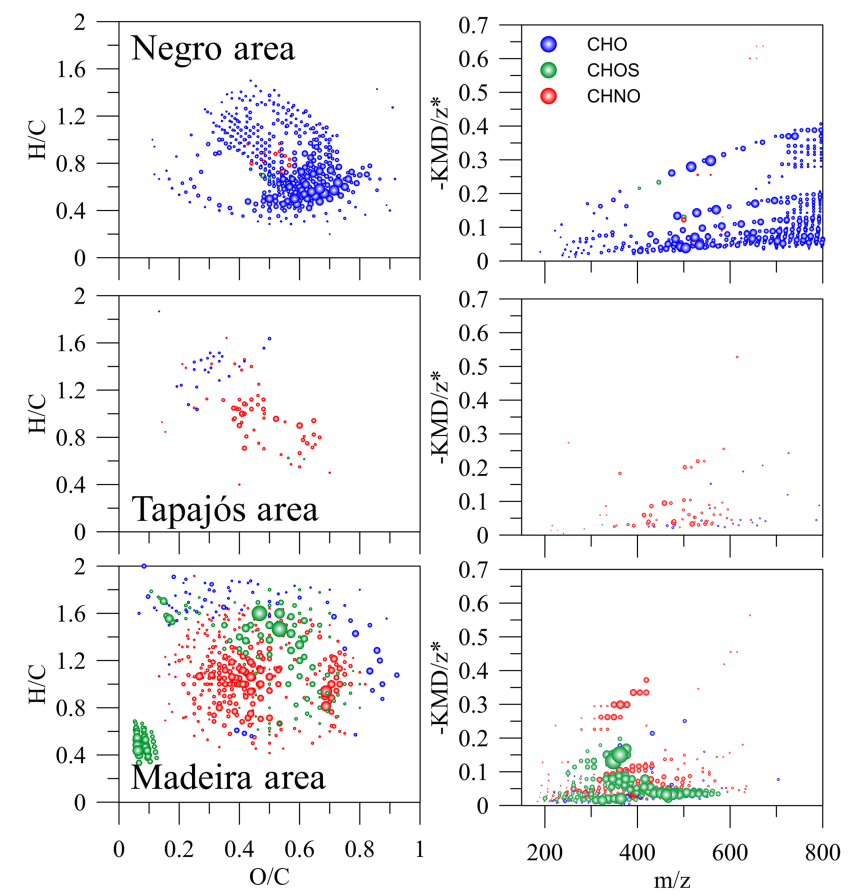

Figure 3. Unique $m / z$ ions analyzed by FT-ICR-MS of solid-phase extracted DOM associated with the three different Amazon areas.

graded tannins or lignins. A large complement of the assigned formulae exceeded the common $\mathrm{O} / \mathrm{C}$ ratios of known lignin or tannic acid subunits and it appeared that these specific Rio Negro polyphenols were highly enriched in oxygen, possibly resulting from microbial side chain oxidation (Kuhnert et al., 2010).

A removal of these unique high molecular weight polyaromatic DOM molecules by means of mineral adsorption or flocculation with iron (Philippe and Schaumann, 2014) or aluminum oxides (Galindo and Del Nero, 2014) after mixing with the high-sediment-load Solimões River is conceivable and corresponded to previous reports that between $4 \%$ (Aucour et al., 2003) and $40 \%$ (Moreira-Turcq et al., 2003) of the DOC was removed at the confluence of the Rio Negro and Solimões. We were not able to sample the Solimões River directly, and hence a direct comparison between FTICR-MS results from the Rio Negro and Solimões were not achieved. However, investigations of Amazon wetland hydrogeochemistry also found analogous preferential sorption of higher molecular weight DOM to sediments, resulting in an enriched low molecular weight aliphatic DOM pool under high suspended solids conditions (Maurice et al., 2002).

In contrast, the distinct signatures indicative of the Rio Madeira area were comprised of diverse CHNO and CHOS compounds that may define the readily bioavailable and labile DOM pool, in part because of its low molecular weight, in particular for the sulfur-bearing $\mathrm{m} / \mathrm{z}$ ions. A specific CHOS pool of very low $\mathrm{H} / \mathrm{C}$ ratios was also apparent in the Madeira area samples. The unique and diverse CHNO and CHOS compounds observed in the Madeira area samples might have indicated anthropogenic influence as suggested in a recent study (Aucour et al., 2003), and this suggestion was supported by the relatively high population living closely to the Madeira sampling area. The city of Porto Velho is about 30 miles upstream of the sampling locations, and the whole area is intensively used for agriculture and to mainly grow soy beans. A potential source of sulfur are sulfonates which may originate from daily care products (e.g., surfactants), but also from wetting agents in fertilizers.

The Tapajós area showed indicative aliphatic CHO signatures (high $\mathrm{H} / \mathrm{C}$ ratios) in the van Krevelen diagram and some diverse nitrogen-containing molecular formulae, but this region was characterized in general by ubiquitous molecular signatures found in all investigated areas. 
EEM spectra of SPE-DOM also showed distinct differences between each area (Fig. S4), and a highly intense longwavelength fluorescent peak in Rio Negro water samples was apparent (Fig. S4). A five-PARAFAC-component (Fmax 15) model (Fig. S2) was most adequate to explain the differences in the fluorescence data set and also captured the indicative fluorescence signal of the Rio Negro (Fmax 3 and 4) at high emission wavelengths (Fig. S5). These high emission wavelengths can either be explained by large complex conjugated $\pi$ systems (Yamaguchi et al., 2008) that would support the unique aromatic high molecular weight DOM characteristic of Rio Negro waters or charge transfer processes (Sharpless and Blough, 2014), which would also require rather complex molecular assemblies.

Additional multivariate analysis, such as HCA and PCA, of the FT-ICR-MS and EEM-PARAFAC data of all samples also produced distinct separation between sampling areas (Fig. 4). It was gratifying that the EEM-PARAFAC PCA and HCA clusters matched remarkably close to the results of the FT-ICR-MS data. These statistical results suggested that many of the molecular changes associated with each sampling area might be associated with certain changes in the fluorescent DOM (FDOM). This at least should apply for the Rio Negro area because FT-ICR-MS-derived molecular signatures showed high hydrogen deficient molecules indicative of aromatic structures. However, correlations between optical properties (EEMs) and FT-ICR-MS data are not a certain proof of a causal relationship.

Traditionally, the classification of Amazon rivers was based on appearance and color of the water, and largely defined by CDOM (e.g., black water - Rio Negro vs. clear water - Rio Tapajós) and its sediment load (e.g., white water - Rio Madeira, Solimões). Hence, optical properties were important indicators, at least for black and clear water systems. Our results suggested that this classification based on optical properties might expand to include specific molecular characteristics of waters from various Amazon Basin areas, but presumably non-fluorescent aliphatic CHOS and CHNO compounds were indicative of the Madeira sampling area and were outside the analytical window of the EEM-PARAFAC approach (Fig. 4). Aromatic CHNO compounds, which were present in the Madeira area samples, presumably carry the ability to show long wavelengths' absorbance and fluorescence, even at relatively low molecular weight. At present, it remains unknown whether aromatic nitrogen heterocyclic compounds play an important role in FDOM.

Our results indicated that classified Amazon water systems (black, white and clear water) were associated with the presence or absence of many regionally unique compounds. It remains an unanswered question as to what happens with the FDOM that is presumably adsorbed to the mineral phase or coagulated and become part of the particulate fraction, and whether or not it is respired or transported to the Atlantic Ocean and eventually desorbed, or if it is added to the downstream sediments or to the seasonally flooded forest floor.
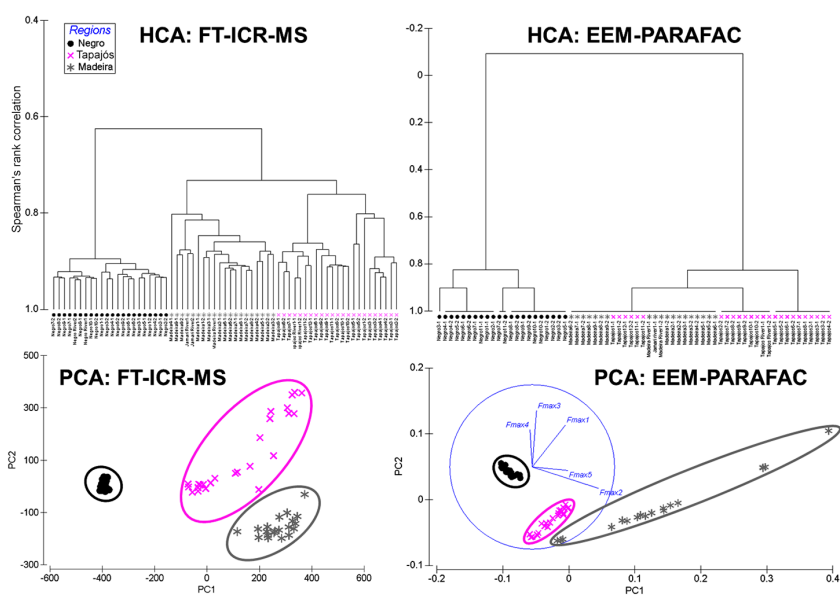

Figure 4. Principal component analysis and hierarchical cluster analysis of the normalized data of all $\mathrm{m} / \mathrm{z}$ ions and their intensities and all EEM-PARAFAC Fmax components.

DOC concentrations in the Rio Negro $\left(10.8 \mathrm{mg} \mathrm{L}^{-1}\right)$ and surrounding lakes $\left(10.1 \mathrm{mg} \mathrm{L}^{-1}\right)$ were twice or more of that of Madeira and Tapajós area waters $\left(1.9-5.8 \mathrm{mg} \mathrm{L}^{-1}\right)(\mathrm{Ta}-$ ble 2), consistent with earlier observations with mean DOC concentrations in the Rio Negro of $12.7 \mathrm{mg} \mathrm{L}^{-1}$, Madeira of $5.8 \mathrm{mg} \mathrm{L}^{-1}$, Solimões $5.8 \mathrm{mg} \mathrm{L}^{-1}$ (not measured in this study) and the Tapajós of $4.5 \mathrm{mg} \mathrm{L}^{-1}$ (Ertel et al., 1986; Richey et al., 1990; Moreira-Turcq et al., 2003). It was also previously stated that the Rio Negro does not produce a simple dilution effect at the confluence with the Solimões (Moreira-Turcq et al., 2003). The Solimões and in particular the Madeira River transport by far the highest load of suspended solids of all tributaries in the Amazon Basin (Moreira-Turcq et al., 2003) and the suggested adsorption, or more likely coagulation, of DOC when mixed with high suspended sediment rivers is conceivable. However, a direct comparison between the Rio Negro and the Solimões at the confluence downstream of Manaus was not undertaken in this study.

High Rio Negro DOC concentrations may be indicative of watershed characteristics (Leenheer, 1980) or a lower mineral content (Moreira-Turcq et al., 2003; Maurice et al., 2002; Aucour et al., 2003) compared to the other tributaries. The DOC data were in agreement with the observations resulting from FT-ICR-MS (Figs. 1 and 3) and EEM-PARAFAC analyses (Fig. S5) that indicated a removal of high molecular weight polyphenolic-like compounds from the Rio Negro waters, when compared to samples collected downstream or in other catchments. Total dissolved nitrogen (TDN) and total dissolved phosphorus (TDP) were low in all waters (Table 2), contributing to the observed low primary productivity despite the differences in light availability between the systems. A high DOM C:N ratio was observed in all waters consistent with previous findings (Ertel et al., 1986; McClain et al., 1995). 
Table 2. Averaged nutrients, chlorophyll, DOC and TDN concentrations of all water samples collected in the main stem of the Rio Negro, Rio Madeira, Rio Jamari and Rio Tapajós as well as in 8-10 flooded lakes within the Rio Negro area, Rio Madeira area as well as within the Rio Tapajós and after its confluence with the Amazon River (Tapajós area) in May 2013.

\begin{tabular}{lrrrrr}
\hline & $\begin{array}{r}\mathrm{DOC}_{\mathrm{av}} \\
\left(\mathrm{mg} \mathrm{L}^{-1}\right)\end{array}$ & $\begin{array}{r}\mathrm{DOC} \text { range } \\
\left(\mathrm{mg} \mathrm{L}^{-1}\right)\end{array}$ & $\begin{array}{c}\mathrm{TDN} \\
\left(\mathrm{mg} \mathrm{L}^{-1}\right)\end{array}$ & $\begin{array}{c}\mathrm{TDP} \\
\left(\mathrm{mg} \mathrm{L}^{-1}\right)\end{array}$ & $\begin{array}{r}\text { Chlorophyll } a \\
\left(\mu \mathrm{L}^{-1}\right)\end{array}$ \\
\hline Rio Negro area (10 flooded lakes and river) & 10.1 & $8.6-11.5$ & 0.12 & 0.01 & 3 \\
Rio Tapajós area (9 flooded lakes and river) & 3.9 & $2.9-5.3$ & 0.10 & 0.03 & 3 \\
Rio Madeira area (10 flooded lakes and river) & 2.9 & $1.9-5.8$ & 0.11 & 0.03 & 2 \\
Rio Tapajós (main stem river only) & 3.6 & & 0.13 & 0.05 & 2 \\
Rio Negro (main stem river only) & 10.6 & & 0.12 & 0.02 & n.d \\
Rio Madeira (main stem river only) & 5.8 & & 0.18 & 0.07 & n.d \\
Rio Jamari (main stem river only) & 2.4 & & 0.23 & 0.04 & 2 \\
(white water tributary to the Madeira River) & & & & & \\
\hline
\end{tabular}

Note: $\mathrm{DOC}_{\mathrm{av}}$ denotes averaged DOC concentrations from each area. Standard error of DOC measurements was always between 0.1 and $0.2 \mathrm{mg}{ }^{-1}$. TDN: total dissolved nitrogen; TDP: total dissolved phosphorus. n.d. denotes not detected. Standard errors of TDN and TDP were always between 0.001 and $0.0025 \mathrm{mg}^{-1}$.

To address the question of which $m / z$ ions were correlated with each other and also with which specific EEMPARAFAC Fmax components, both data sets were combined, normalized and correlated using Spearman's rank correlations (Fig. 5). All variables were statistically compared within the dissolved organic carbon (CHO), dissolved organic nitrogen (CHNO) and the dissolved organic sulfur (CHOS) pools (Figs. 5 and S6). Heat maps revealed clearly distinct hierarchical clusters in each of the $\mathrm{CHO}, \mathrm{CHNO}$ and CHOS pools, indicative of a very similar behavior of variables within individual clusters. Remarkably, large clusters in the $\mathrm{CHO}$ pool were found which represented rather confined molecular ions with specific $\mathrm{O} / \mathrm{C}$ and $\mathrm{H} / \mathrm{C}$ ratios (Fig. S6). One unique $\mathrm{CHO}$ cluster consisted of hydrogen-deficient (low $\mathrm{H} / \mathrm{C}$ ), but highly oxygenated (high $\mathrm{O} / \mathrm{C}$ ) molecular ions and had a strong positive correlation with all Rio Negro samples (Fig. S7). Similarly, the Fmax components 3 and 4 were highly correlated to a cluster of high molecular weight molecular ions (Figs. 5 and S7). This unique DOM signature showed much higher $\mathrm{O} / \mathrm{C}$ ratios when compared to known lignins and tannic acids and may resemble the result of humification and an increase in non-lignin aromatic structures and higher carboxyl group content (Zech et al., 1997).

In contrast, Fmax 1,2 and 5 only correlated with a very few aliphatic molecular ions (Figs. 5 and S6), which were improbable fluorescent compounds itself, indicating an indirect correlation. Accordingly, correlations of Fmax 1, 2 and 5 were found within a distinct $\mathrm{CHNO}$ cluster, indicating that the fluorophores responsible for these PARAFAC components might have derived from heterocyclic or other aromatic nitrogen-containing molecules. However, components Fmax 3 and 4 did not show any correlation with molecular ions in the CHNO pool, nor in the CHOS pool, supporting the supposition that these PARAFAC components were only derived from $\mathrm{CHO}$ molecules.
The heat map and correlations of CHOS molecular ions (Fig. S6) reflected the already mentioned enrichment of CHOS compounds in the Madeira and Tapajós area samples and the absence of these signatures in the Rio Negro area. The unique highly hydrogen-deficient CHOS pool only found in the Madeira sampling area also manifested in a distinct cluster in this analysis. The CHOS-based cluster that covaried with PARAFAC components Fmax 1, 2 and 5 showed mostly molecular ions with high $\mathrm{O} / \mathrm{C}$ ratios, and a high probability to be aromatic indicated by a subset of formulae that showed $\mathrm{H} / \mathrm{C}$ ratios below 1. In contrast to the $\mathrm{CHO}$ pool that correlated with Fmax 3 and 4, this specific CHOS pool was confined to the low molecular weight range. At this point, it appears that CHOS molecules also contributed to the fluorescence signals manifested in Fmax 1, 2 and 5. Overall, Fmax 1, 2 and 5 always correlated together as did Fmax 3 and 4. A simple Spearman's rank correlation between the PARAFAC components confirmed the very strong correlations between these two clusters (Fig. S7).

Here, we present direct evidence that Rio Negro waters contained a unique, high molecular weight and highly fluorescent DOM component that is neither present in the Rio Madeira nor in the Rio Tapajós/Amazon confluence. This Rio Negro FDOM was confirmed by FT-ICR-MS to be indicative of high molecular weight polyphenolic-like compounds. DOC concentrations were also the highest in the Rio Negro. There is no reason to suspect widely different DOC produced by plants among the regions, but differences in geology is expected to influence the DOC pool, which is in part reflected in the large differences in $\mathrm{pH}$ and it is likely that this specific Rio Negro DOM fraction is sensitive to adsorption to mineral particles or coagulation with metals and that this specific DOM can be rapidly removed from the water during mixing of major Amazon tributaries as suggested in previous studies (Moreira-Turcq et al., 2003; Aucour et al., 2003). Such a removal would also substantially reduce the 


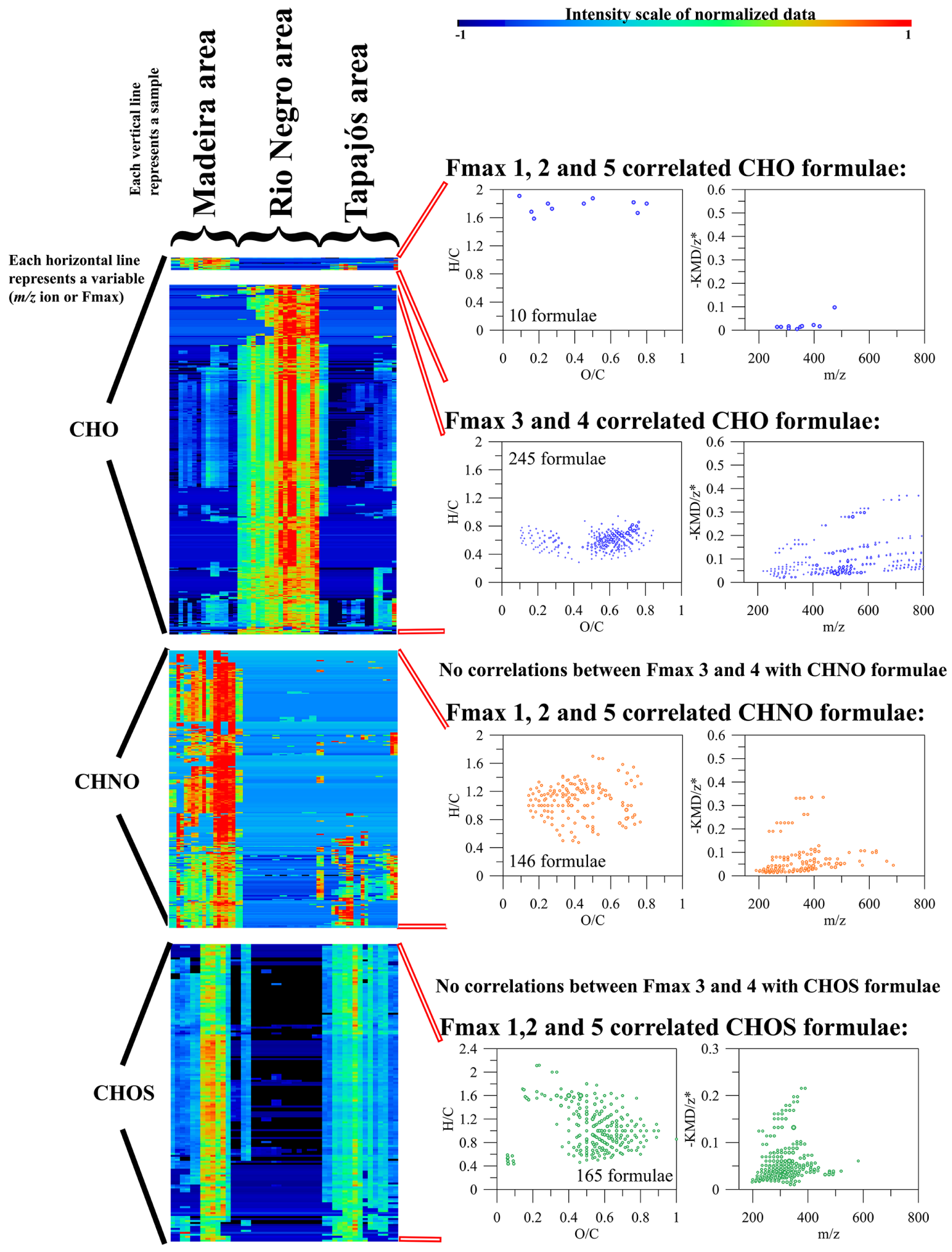

Figure 5. Heat maps of specific Spearman's rank-correlated hierarchical clusters (distance threshold 0.6) that showed correlations between $\mathrm{m} / \mathrm{z}$ ions and Fmax values separated into the dissolved organic carbon $(\mathrm{CHO})$ nitrogen $(\mathrm{CHNO})$ and sulfur (CHOS) pool. The van Krevelen diagrams correspond to the molecular signatures that co-varied with specific EEM-PARAFAC Fmax values. The entire heat maps and additional specific $\mathrm{m} / \mathrm{z}$ ion clusters are given in Fig. S6, including their distribution in the chemical space visualized in van Krevelen diagrams. 
molecular complexity of Amazon DOM as observed in this study.

The similarities in DOM quality within regions between lakes and rivers (Table 2) indicated that the DOM composition is relatively stable under certain sets of environmental conditions. On the other hand, as discussed above, changing conditions may rapidly change DOM composition, in turn affecting conditions for aquatic life. While the commonly measured spectral properties of the DOM indicated these overall patterns, some important details were missed by solely measuring optical properties. Distinction between unique types of DOM with different origin, functions and turnover times, such as the previously discussed CHNO and CHOS compounds, would not have been possible without FT-ICR-MS and multivariate statistical analyses. Thus, for improved capacity to understand and predict the fates and functions of DOM, new methods, such as ultrahigh-resolution FT-ICRMS, allowed detailed DOM characterization and emphasized the importance of non-target high-resolution techniques. To stimulate additional comparisons of simultaneously collected FT-ICR-MS and EEM-PARAFAC data, we encourage researchers to freely access the data sets used in this study (Gonsior et al. 2016).

\section{Data availability}

All FT-ICR-MS and EEM-PARAFAC data are freely available online (Gonsior et al., 2016).

\section{The Supplement related to this article is available online at doi:10.5194/bg-13-4279-2016-supplement.}

Acknowledgements. This research was supported by the Brazilian research agencies FAPERJ, CAPES and CNPq, by the German research agencies Alexander von Humboldt and DAAD and the Swedish Research agencies STINT and VR. Alex Enrich-Prast has additional support as a research fellow from $\mathrm{CNPq}$ and a Cientista do Nosso Estado from FAPERJ. This is contribution 5207 of the University of Maryland Center for Environmental Science, Chesapeake Biological Laboratory.

Edited by: M. Tzortziou

Reviewed by: two anonymous referees

\section{References}

Amado, A. M., Farjalla, V. F., Esteves, F. D. A., Bozelli, R. L., Roland, F., and Enrich-Prast, A.: Complementary pathways of dissolved organic carbon removal pathways in clear-water Amazonian ecosystems: photochemical degradation and bacterial uptake, Fems Microbiol. Ecol., 56, 8-17, doi:10.1111/j.15746941.2006.00028.x, 2006.
Aucour, A. M., Tao, F. X., Moreira-Turcq, P., Seyler, P., Sheppard, S., and Benedetti, M. F.: The Amazon River: behaviour of metals (Fe, Al, Mn) and dissolved organic matter in the initial mixing at the Rio Negro/Solimões confluence, Chem. Geol., 197, 271-285, doi:10.1016/S0009-2541(02)00398-4, 2003.

Benner, R., Opsahl, S., ChinLeo, G., Richey, J. E., and Forsberg, B. R.: Bacterial carbon metabolism in the Amazon River system, Limnol. Oceanogr., 40, 1262-1270, 1995.

Boutegrabet, L., Kanawati, B., Gebefügi, I., Peyron, D., Cayot, P., Gougeon, R. D., and Schmitt-Kopplin, P.: Attachment of Chloride Anion to Sugars: Mechanistic Investigation and Discovery of a New Dopant for Efficient Sugar Ionization/Detection in Mass Spectrometers, Chem.-Eur. J., 18, 13059-13067, doi:10.1002/chem.201103788, 2012.

Bro, R. and Smilde, A. K.: Principal component analysis, Anal. Meth., 6, 2812-2831, doi:10.1039/c3ay41907j, 2014.

Centre national pour l'exploitation des océans (France): Manuel des analyses chimiques en milieu marin, edited by: Aminot, A. and Chaussepied, M., CNEXO, Brest, 395 pp., 1983.

Chen, M., Price, R. M., Yamashita, Y., and Jaffe, R.: Comparative study of dissolved organic matter from groundwater and surface water in the Florida coastal Everglades using multi-dimensional spectrofluorometry combined with multivariate statistics, Appl. Geochem., 25, 872-880, doi:10.1016/j.apgeochem.2010.03.005, 2010.

Costa, M. P. F., Novo, E., and Telmer, K. H.: Spatial and temporal variability of light attenuation in large rivers of the Amazon, Hydrobiologia, 702, 171-190, doi:10.1007/s10750-012-1319-2, 2013.

D’Andrilli, J., Dittmar, T., Koch, B. P., Purcell, J. M., Marshall, A. G., and Cooper, W. T.: Comprehensive characterization of marine dissolved organic matter by Fourier transform ion cyclotron resonance mass spectrometry with electrospray and atmospheric pressure photoionization, Rapid Commun. Mass Sp., 24, 643650, 2010.

Dittmar, T., Koch, B., Hertkorn, N., and Kattner, G.: A simple and efficient method for the solid-phase extraction of dissolved organic matter (SPE-DOM) from seawater, Limnol. Oceanogr.Meth., 6, 230-235, 2008.

Duncan, W. and Fernandes, M.: Physicochemical characterization of the white, black, and clearwater rivers of the Amazon Basin and its implications on the distribution of freshwater stingrays (Chondrichthyes, Potamotrygonidae), Pan-American Journal of Aquatic Sciences, 5, 454-464, 2010.

Ertel, J. R., Hedges, J. I., Devol, A. H., and Richey, J. E.: Dissolved Humic Substances of the Amazon River System, Limnol. Oceanogr., 31, 739-754, 1986.

Farjalla, V. F., Esteves, F. A., Bozelli, R. L., and Roland, F.: Nutrient limitation of bacterial production in clear water Amazonian ecosystems, Hydrobiologia, 489, 197-205, doi:10.1023/a:1023288922394, 2002.

Flerus, R., Koch, B. P., Schmitt-Kopplin, P., Witt, M., and Kattner, G.: Molecular level investigation of reactions between dissolved organic matter and extraction solvents using FT-ICR MS, Mar. Chem., 124, 100-107, doi:10.1016/j.marchem.2010.12.006, 2011.

Galindo, C. and Del Nero, M.: Molecular Level Description of the Sorptive Fractionation of a Fulvic Acid on Aluminum Oxide Using Electrospray Ionization Fourier Transform 
Mass Spectrometry, Environ. Sci. Technol., 48, 7401-7408, doi:10.1021/es501465h, 2014.

Gaspar, A., Kunenkov, E. V., Lock, R., Desor, M., Perminova, I., and Schmitt-Kopplin, P.: Combined utilization of ion mobility and ultra-high-resolution mass spectrometry to identify multiply charged constituents in natural organic matter, Rapid Commun. Mass Sp., 23, 683-688, doi:10.1002/rcm.3924, 2009.

Gonsior, M., Peake, B. M., Cooper, W. T., Podgorski, D. C., D'Andrilli, J., Dittmar, T., and Cooper, W. J.: Characterization of dissolved organic matter across the Subtropical Convergence off the South Island, New Zealand, Mar. Chem., 123, 99-110, doi:10.1016/j.marchem.2010.10.004, 2011.

Gonsior, M., Schmitt-Kopplin, P., and Bastviken, D.: Depthdependent molecular composition and photo-reactivity of dissolved organic matter in a boreal lake under winter and summer conditions, Biogeosciences, 10, 6945-6956, doi:10.5194/bg-106945-2013, 2013.

Gonsior, M., Valle, J., Schmitt-Kopplin, P., Hertkorn, N., Bastviken, D., Luek, J., Harir, M., Bastos, W., and Enrich-Prast, A.: Data from: Chemodiversity of dissolved organic matter in the Amazon Basin, Dryad Digital Repository, doi:10.5061/dryad.r44rh, 2016.

Hedges, J. I., Hatcher, P. G., Ertel, J. R., and Meyers-Schulte, K. J.: A comparison of dissolved humic substances from seawater with Amazon River counterparts by carbon-13 NMR spectrometry, Geochim. Cosmochim. Ac., 56, 1753-1757, 1992.

Hedges, J. I., Cowie, G. L., Richey, J. E., Quay, P. D., Benner, R., Strom, M., and Forsberg, B. R.: Origins and processing of organic matter in the Amazon River as indicated by carbohydrates and amino acids, Limnol. Oceanogr., 39, 743-761, doi:10.4319/lo.1994.39.4.0743, 1994.

Hedges, J. I., Mayorga, E., Tsamakis, E., McClain, M. E., Quay, P., Richey, J. E., Benner, R., Opsahl, S., Black, B., Pimentel, T., Quintanilla, J., and Maurice, L.: Organic matter in Bolivian tributaries of the Amazon River: A comparison to the lower mainstream, Limnol. Oceanogr., 45, 1449-1466, doi:10.4319/lo.2000.45.7.1449, 2000.

Hertkorn, N., Frommberger, M., Witt, M., Koch, B., SchmittKopplin, P., and Perdue, E. M.: Natural Organic Matter and the Event Horizon of Mass Spectrometry, Anal. Chem., 80, 89088919, doi:10.1021/ac800464g, 2008.

Hertkorn, N., Harir, M., Koch, B. P., Michalke, B., and SchmittKopplin, P.: High-field NMR spectroscopy and FTICR mass spectrometry: powerful discovery tools for the molecular level characterization of marine dissolved organic matter, Biogeosciences, 10, 1583-1624, doi:10.5194/bg-10-1583-2013, 2013.

Horbe, A. M. C., Queiroz, M. M. D., Moura, C. A. V., and Toro, M. A. G.: Chemistry of waters of the middle and lower Madeira River and its main tributaries - Amazonas - Brazil, Acta Amazonica, 43, 489-504, 2013.

Johnson, M. S., Lehmann, J., Selva, E. C., Abdo, M., Riha, S., and Couto, E. G.: Organic carbon fluxes within and streamwater exports from headwater catchments in the southern Amazon, Hydrol. Process., 20, 2599-2614, doi:10.1002/hyp.6218, 2006.

Junk, W. J.: Ecology of the várzea, floodplain of Amazonian whitewater rivers, in: The Amazon, edited by: Sioli, H., Monographiae Biologicae, Springer, the Netherlands, 215-243, 1984.

Kendrick, E.: A mass scale based on $\mathrm{CH}_{2}=14.0000$ for high resolution mass spectrometry of organic compounds, Anal. Chem., 35, 2146-2154, doi:10.1021/ac60206a048, 1963.
Kuhnert, N., Drynan, J. W., Obuchowicz, J., Clifford, M. N., and Witt, M.: Mass spectrometric characterization of black tea thearubigins leading to an oxidative cascade hypothesis for thearubigin formation, Rapid Commun. Mass Sp., 24, 33873404, doi:10.1002/rcm.4778, 2010.

Leenheer, J. A.: Origin and Nature of Humic Substances in the Waters of the Amazon River Basin, Acta Amazonica, 10, 513-526, 1980.

Liu, Z. F., Sleighter, R. L., Zhong, J. Y., and Hatcher, P. G.: The chemical changes of DOM from black waters to coastal marine waters by HPLC combined with ultrahigh resolution mass spectrometry, Estuar. Coast Shelf S., 92, 205-216, doi:10.1016/j.ecss.2010.12.030, 2011.

Luciani, X., Mounier, S., Paraquetti, H. H. M., Redon, R., Lucas, Y., Bois, A., Lacerda, L. D., Raynaud, M., and Ripert, M.: Tracing of dissolved organic matter from the SEPETIBA Bay (Brazil) by PARAFAC analysis of total luminescence matrices, Mar. Environ. Res., 65, 148-157, doi:10.1016/j.marenvres.2007.09.004, 2008.

Maurice, P. A., Cabaniss, S. E., Drummond, J., and Ito, E.: Hydrogeochemical controls on the variations in chemical characteristics of natural organic matter at a small freshwater wetland, Chem. Geol., 187, 59-77, doi:10.1016/S0009-2541(02)00016-5, 2002.

McClain, M. E., Richey, J. E., and Reynaldo, L. V.: Andean Contributions to the Biogeochemistry of the Amazon River System, Bull. Inst. fr. études andines, 24, 425-437, 1995.

McClain, M. E., Richey, J. E., Brandes, J. A., and Pimentel, T. P.: Dissolved organic matter and terrestrial-lotic linkages in the central Amazon basin of Brazil, Global Biogeochem. Cy., 11, 295311, doi:10.1029/97gb01056, 1997.

Moreira-Turcq, P., Seyler, P., Guyot, J. L., and Etcheber, H.: Exportation of organic carbon from the Amazon River and its main tributaries, Hydrol. Process., 17, 1329-1344, doi:10.1002/hyp.1287, 2003.

Moreira-Turcq, P., Bonnet, M. P., Amorim, M., Bernardes, M., Lagane, C., Maurice, L., Perez, M., and Seyler, P.: Seasonal variability in concentration, composition, age, and fluxes of particulate organic carbon exchanged between the floodplain and Amazon River, Global Biogeochem. Cy., 27, 119-130, doi:10.1002/gbc.20022, 2013.

Murphy, K. R., Stedmon, C. A., Graeber, D., and Bro, R.: Fluorescence spectroscopy and multi-way techniques. PARAFAC, Anal Meth., 5, 6557-6566, doi:10.1039/c3ay41160e, 2013.

Patel-Sorrentino, N., Mounier, S., and Benaim, J. Y.: Excitationemission fluorescence matrix to study $\mathrm{pH}$ influence on organic matter fluorescence in the Amazon basin rivers, Water Res., 36, 2571-2581, doi:10.1016/S0043-1354(01)00469-9, 2002.

Philippe, A. and Schaumann, G. E.: Interactions of Dissolved Organic Matter with Natural and Engineered Inorganic Colloids: A Review, Environ. Sci. Technol., 48, 8946-8962, doi:10.1021/es502342r, 2014.

Quay, P. D., Wilbur, D. O., Richey, J. E., Hedges, J. I., Devol, A. H., and Victoria, R.: Carbon cycling in the Amazon River: Implications from the 13C compositions of particles and solutes, Limnol. Oceanogr., 37, 857-871, 1992.

Richey, J. E., Hedges, J. I., Devol, A. H., Quay, P. D., Victoria, R., Martinelli, L., and Forsberg, B. R.: Biogeochemistry of Carbon in the Amazon River, Limnol. Oceanogr., 35, 352-371, 1990. 
Shakeri Yekta, S., Gonsior, M., Schmitt-Kopplin, P., and Svensson, B. H.: Characterization of Dissolved Organic Matter in Full Scale Continuous Stirred Tank Biogas Reactors Using Ultrahigh Resolution Mass Spectrometry: A Qualitative Overview, Environ. Sci. Technol., 46, 12711-12719, doi:10.1021/es3024447, 2012.

Sharpless, C. M. and Blough, N. V.: The importance of chargetransfer interactions in determining chromophoric dissolved organic matter (CDOM) optical and photochemical properties, Environmental Science: Processes \& Impacts, 16, 654-671, doi:10.1039/c3em00573a, 2014.

Sioli, H.: Das Wasser im Amazonasgebiet, Forschungen und Fortschritte, 26, 274-280, 1950.

Sleighter, R. L., Liu, Z., Xue, J., and Hatcher, P. G.: Multivariate Statistical Approaches for the Characterization of Dissolved Organic Matter Analyzed by Ultrahigh Resolution Mass Spectrometry, Environ. Sci. Technol., 44, 7576-7582, doi:10.1021/es1002204, 2010.

Stedmon, C. A., Markager, S., and Bro, R.: Tracing dissolved organic matter in aquatic environments using a new approach to fluorescence spectroscopy, Mar. Chem., 82, 239-254, doi:10.1016/S0304-4203(03)00072-0, 2003.

Stenson, A. C., Landing, W. M., Marshall, A. G., and Cooper, W. T.: Ionization and Fragmentation of Humic Substances in Electrospray Ionization Fourier Transform-Ion Cyclotron Resonance Mass Spectrometry, Anal. Chem., 74, 4397-4409, 2002.

Stenson, A. C., Marshall, A. G., and Cooper, W. T.: Exact Masses and Chemical Formulas of Individual Suwannee River Fulvic Acids from Ultrahigh Resolution Electrospray Ionization Fourier Transform Ion Cyclotron Resonance Mass Spectra, Anal. Chem., 75, 1275-1284, 2003.

Stubbins, A., Spencer, R. G. M., Chen, H., Hatcher, P. G., Mopper, K., Hernes, P. J., Mwamba, V. L., Mangangu, A. M., Wabakanghanzi, J. N., and Six, J.: Illuminated darkness: molecular signatures of Congo River dissolved organic matter and its photochemical alteration as revealed by ultrahigh precision mass spectrometry, Limnol. Oceanogr., 55, 1467-1477, doi:10.4319/lo.2010.55.4.1467, 2010.
Stubbins, A., Lapierre, J. F., Berggren, M., Prairie, Y. T., Dittmar, T., and del Giorgio, P. A.: What's in an EEM? Molecular Signatures Associated with Dissolved Organic Fluorescence in Boreal Canada, Environ. Sci. Technol., 48, 10598-10606, doi:10.1021/es502086e, 2014.

Townsend-Small, A., Noguera, J. L., McClain, M. E., and Brandes, J. A.: Radiocarbon and stable isotope geochemistry of organic matter in the Amazon headwaters, Peruvian Andes, Global Biogeochem. Cy., 21, GB2029, doi:10.1029/2006gb002835, 2007.

Tremblay, L. B., Dittmar, T., Marshall, A. G., Cooper, W. J., and Cooper, W. T.: Molecular characterization of dissolved organic matter in a North Brazilian mangrove porewater and mangrovefringed estuaries by ultrahigh resolution Fourier Transform-Ion Cyclotron Resonance mass spectrometry and excitation/emission spectroscopy, Mar. Chem., 105, 15-29, 2007.

van Krevelen, D. W.: Graphical-statistical method for the study of structure and reaction processes of coal, Fuel, 29, 269-284, 1950.

Ward, N. D., Keil, R. G., Medeiros, P. M., Brito, D. C., Cunha, A. C., Dittmar, T., Yager, P. L., Krusche, A. V., and Richey, J. E.: Degradation of terrestrially derived macromolecules in the Amazon River, Nat. Geosci., 6, 530-533, doi:10.1038/ngeo1817, 2013.

Werner, E., Croixmarie, V., Umbdenstock, T., Ezan, E., Chaminade, P., Tabet, J.-C., and Junot, C.: Mass spectrometrybased metabolomics: Accelerating the characterization of discriminating signals by combining statistical correlations and ultrahigh resolution, Anal. Chem., 80, 4918-4932, doi:10.1021/ac800094p, 2008.

Yamaguchi, Y., Matsubara, Y., Ochi, T., Wakamiya, T., and Yoshida, Z.-i.: How the $\pi$ Conjugation Length Affects the Fluorescence Emission Efficiency, J. Am. Chem. Soc., 130, 13867-13869, doi:10.1021/ja8040493, 2008.

Zech, W., Senesi, N., Guggenberger, G., Kaiser, K., Lehmann, J., Miano, T. M., Miltner, A., and Schroth, G.: Factors controlling humification and mineralization of soil organic matter in the tropics, Geoderma, 79, 117-161, doi:10.1016/S00167061(97)00040-2, 1997. 